УДК 130.12:172.1:304.4

С. В. Киселиця, к. філос. н., доцент

\title{
ГРОМАДСЬКА ДУМКА ЯК МОРАЛЬНО-ПОЛІТИЧНИЙ РЕГУЛЯТИВ ЛЮДСЬКОГО БУТТЯ
}

Актуальність теми дослідження. Однією із перманентних проблем людської спільноти $\epsilon$ ефрективний вплив на довкілля, зокрема на соціум.

Постановка проблеми. Особливої актуальності набуває дослідження громадської думки в контексті особистісної ізольованості та національної відцентрованості останніх десятиліть, які чітко вияляються у запеклій боротьбі за статус тієї чи іншої комунікаційноуправлінської доктрини.

Аналіз останніх досліджень і публікацій. Наразі взаємопроникнення моралі й політики неминуче призводить до граничного напруження в гуманітарних науках через перетин тут ірраціонально-чуттєвої (психологія, антропологія, етнологія) $і$ раціонально-вольової (політологія, соціологія, етика) царин, пов'язаних із формуванням самосвідомості та цивілізованих форм спілкування.

Визначення раніше недосліджених частин загальної проблеми. Поєднання різноманітних інтересів людини - це завжди випробування для політики як мистецтва можливого і для моралі як соціоментальної основи людського буття.

Постановка задачі. Метою статті є аналіз комунікативно-регулятивної специфріки громадської думки та способи впливу на неї моралі й політики.

Виклад основного матеріалу. Людина в процесі соціалізації, яка одномоментно здійснюється в суперечливих унікально-універсальних параметрах, намагається якомога точніше осягнути можливості персонального впливу на навколишнє середовище. Автор використовує методи спостереження, анкетування, ідеалізації, моделювання та компаративного аналізу. Основна гіпотеза - менталітет народу формує владу $і$ через громадську думку (панівні світоглядні алгоритми у буденній (масовій) свідомості) впливає на політику.

Висновки. Громадська думка виступає єдиним надійним посередником або продуктивним компромісом між мораллю і політикою, що гарантує гармонійне співіснування влади і народу в перспективному соціумі. Чим консолідованішу позицію демонструє народ, тим більш підконтрольною і цивілізованою (моральною) стає влада i чим гнучкіша влада, тим більш політично грамотним виявляється народ; обопільним наслідком є формування громадянської свідомості.

Ключові слова: громадянська свідомість; комунікація; менталітет; світогляд; мораль; громадська думка; буденна свідомість; політика; людське буття.

S. V. Kyselytsia, Candidate of Philosophical Sciences, Associate Professor

\section{PUBLIC OPINION AS A MORAL AND POLITICAL REGULATION OF HUMAN BEING}

Urgency of the research. Effective influence on the surrounding world is the most important problem of human society.

Target setting. The study of public opinion in the context of the personal and national centrifugality of recent decades, manifested in the struggle for the dominance of one or another communication paradigm is of particular relevance.

Actual scientific researches and issues analysis. The interpenetration of morality and politics inevitably leads to extreme tension in the humanitarian sciences due to the intersection here of the irrational-sensual (social psychology, anthropology, ethnology) and rational-volitional (political science, sociology, ethics) spheres associated with the formation of self-consciousness and the creation of civilized forms of communication. 
Uninvestigated parts of general matters defining. The combination of various interests is always a test for politics as the art of the possible and for morality as the mental basis of human existence.

The research objective. The purpose of the article is to analyze the communicative and regulatory specifics of public opinion.

The statement of basic materials. A person in the process of socialization, simultaneously existing in a contradictory uniquely universal dimensions, tries to comprehend the possibilities of personal influence on the environment. The author uses methods of observation, questioning, idealization, modeling and comparative analysis. The main hypothesis is that the mentality of people forms the power and through public opinion (the dominant worldview algorithms in the mass consciousness) influences the politics.

Conclusions. Public opinion is the only reliable mediator or productive compromise between morality and politics, guaranteeing the harmonious coexistence of power and people in a promising society. The more consolidated position the people demonstrate, the more controllable and civilized (moral) the power is, the more flexible the power, the more politically literate the people become and, as a result, the civil consciousness is formed.

Keywords: civil consciousness; communication; mentality; worldview; morality; public opinion; mass consciousness; politics; human being.

DOI: 10.25140/2412-1185-2019-2(14)-42-51

Актуальність теми дослідження. Перманентною проблемою людської спільноти $\epsilon$ ефективний вплив на навколишнє середовище. Актуальність дослідження моралі і політики в сучасному соціокультурному просторі обумовлено пошуком їх гармонійної взаємодії, в якому громадська думка виступає основним ціннісно-комунікативним регулятивом. Відтак, їх очевидна взаємозалежність неминуче призводить до граничного напруження в гуманітарній царині через перетин тут ірраціонально-чуттєвої (психологія, антропологія, етнологія) і раціонально-вольової (політологія, соціологія, етика) складових людського буття, пов'язаних з формуванням громадянської позиції, а відтак, і самосвідомості та створенням цивілізованих форм спілкування.

Постановка проблеми. Нерозуміння механізму взаємопроникнення моралі і політики можуть істотно обмежити можливості народу впливати на владу, залишивши йому лише традиції, звичаї, менталітет, побутову культуру, міфологію тощо, а владу позбавити можливості успішного впровадження з ії точки зору привабливої ідеологічної доктрини в суспільну свідомість. При цьому створення державою цивілізованих правил спілкування між людьми, родинами, кланами, класами, спільнотами, референтними групами, етносами i, насамкінець, владою і народом, часто має декларативний характер, де відповідальність за хибні рішення, фактично, перекладається на мудрий народ, який завжди точно знає, як треба жити, адже всі, нібито, помилятись не можуть.

Аналіз останніх досліджень і публікацій. Інтегративний погляд на проблематику передбачає переосмислення основоположних принципів взаємодії народу і влади, моралі i політики, які виявляються в так званих вердиктах сторін: громадській думці і державних законах. Яскравим свідченням щирої зацікавленості у вирішенні вищевикладених проблем, на наш погляд, $€$ теоретико-світоглядні розробки українських філософрів, істориків, політологів, соціологів Є. Андроса, В. Андрущенка, О. Балакірєвої, І. Бекешкіної, І. Бондарчук, М. Бойченка, Т. Гардашук, Є. Головахи, А. Єрмоленка, О. Корнієвського, О. Крука, С. Крилової, С. Кримського, С. Кульчицького, Т. Лютого, В. Малахова, М. Мінакова, М. Поповича, М. Препотенскої, С. Пролеєва, В. Табачковського, Ю. Терещенка, Н. Хамітова, В. Шинкарука, О. Яценка та інших.

Визначення раніше недосліджених частин загальної проблеми. Особливо гостро в глобальному світі постають проблеми ефективного впливу народу на державні інституції та успішна імплементація владних проектів у широкі верстви населення. Демаркація понять моралі і політики призводить до необхідності ретельного дослідження способів впливу громадської думки (в певному сенсі, архетипів, глибинної свідомості народних мас) на політичні, правові, ідеологічні алгоритми дій державних чиновників і навпаки. Труднощі, які очікують дослідників на цьому шляху, зумовлені категоріальною і феноменальною розмитістю меж кожної з них та запеклою боротьбою за потужний вплив на соціум. 
Постановка завдання. Змістовною спрямованістю цього дискурсу $є$ визнання соціокультурної значущості громадської думки, дієвість якої є вистражданою формою єднання різнорідних професійних, вікових, гендерних, конфесійних тощо соціальних груп, внутрішньоетнічним і міжетнічним комунікатором мирного співіснування - «всім миром, всім народом». Виходячи з цього, метою статті $€$ аналіз комунікативно-регулятивної специфіки громадської думки.

Виклад основного матеріалу. Сучасний глобальний світ, що інтенсивно змінюється, змушує людину все активніше шукати адекватні адаптаційні форми взаємодії, а відтак, ефрективніші моделі управління та самоуправління. Менталітет, очевидно, завжди фоормється через подолання суперечливості одноосібного й колективного у людській спільноті. Процес ментальної ідентифікації недостатньо вивчений гуманітарними науками і, як нам уявляється актуальним, вимагає інтегративного підходу в пошуках надійної морально-політичної моделі подальшого співіснування всіх соціальних суб'єктів. Таким чином, одним із надважливих завдань сучасного людинознавства $€$ вивчення природи формування громадської думки та методи впливу на неї моралі й політики.

Основна гіпотеза нашого дослідження - менталітет народу формує владу і через громадську думку (панівні світоглядні установки у буденній свідомості) впливає на ідеологію і навпаки. Ментальність, як правило, ототожнюється з повсякденністю, а народ розглядається як кількісна домінанта по відношенню до влади. Але необхідність якісно облаштовувати свій духовний простір поряд 3 матеріальним, повинна приводити його до усвідомлення особистісної відповідальності і, як наслідок, обов'язковість формування громадянської позиції. Людина, виходячи з суперечливості власної природи, в силу антропологічної і соціальної роздвоєності, змушена одночасно як адаптуватися до середовища проживання, так і змінювати його. Творити себе та історію свого роду (чи, ширше, країни) означає намагатися цивілізовано ставитися до природного і суспільного ареалу. Цей характерний для людського буття стан, очевидно, трансформується в унікальну світоглядно-психологічну настанову, що визначається як потреба у впливовості. Саме в цій екзистенціальній точці й формується взаємозалежність народу і влади, моралі і політики.

Самоідентифікація як особистості, так і народу $є$ надзвичайно складним, тривалим, делікатним процесом. Різновекторність прагнень конгломерату - це завжди випробування на міцність для влади та її політики, прийнятої в якості ідеологічної доктриини. Необхідність зважати на різноманіттям мислеформ призводить до вольового, інтелектуального, емоційного напруження, пов'язаного з пошуком і виробленням цивілізованих способів комунікації як в міжособистісному, так і політичному просторі.

Поняття «суспільство», як випливає з етимології слів у більшості європейських мов - похідна від поняття «загальне», «спілкування». Тому особливо гострою в глобальному світі $є$ проблема комунікаційної культури. Вона постає перед сучасними фрілософами, політологами, психологами, культурологами, релігієзнавцями, антропологами, соціологами у вигляді імплементації громадської думки у вищі ешелони влади, іншими словами, ненав'язливого, але непохитного її проникнення в державну політику і, тим самим, удосконалення чи викорінення діючої управлінської моделі. У цілісному людському бутті цей процес для дієздатного громадянина і відповідального політика ототожнюється з пошуком взаємоприйнятних умов реалізації їх права впливати на суспільну свідомість, яка «ніколи не може бути чимсь іншим, як тільки усвідомленням буття (das bewusste Sein), а буття людей - це реальний їхній життьовий процес» [1, с. 25].

Успішна самоідентифікація на рівні суспільної свідомості передбачає ретельний аналіз істотних структурних елементів людського буття: природного місця існування; фрізичних, біологічних або генетичних особливостей носіїв свідомості; культурної спадщини; історичних традицій та історіософського досвіду; виробничих взаємин; менталітету, онтологічним проявом якого є морально-політична діяльність соціальних суб'єктів.

Соціум сучасної людини вимагає особливої уваги на тлі відцентрових тенденцій останніх десятиліть, не останньою чергою пов'язаних з розпадом конгломерату під назвою радянський народ. В умовах глобалізації процес самоідентифікації щодо міжнародних пріоритетів не може так довго перебувати в стані теоретико-методологічної невизначеності (особливо в країнах Євросоюзу, які перебувають зараз на стадії переформатування), інакше дуже швидко і, головне, 
неконтрольовано кількість може перейти в далеку від очікуваної якість і вже не в теоретичному, а практичному значенні.

Київська Русь, успішна тогочасна европейська держава, за тисячу років до сьогодення продемонструвала ефрективність взаємопроникнення моралі і політики в управлінській парадигмі через віче, у феномені якого можемо знайти органічне взаємодоповнення буденної свідомості пересічної людини та княжої ідеології. Тут всі соціально-політичні події в тій чи іншій мірі були пов'язані з етнокультурним досвідом, що поєднав ментальні «віяння» північно-західної та південносхідної Європи, Малої Азії, тим самим створив оригінальні форми комунікації як між владою і народом, так і між різними верствами всередині суспільства. 3 теоретико-світоглядної точки зору щодо їх гармонійного співіснування показовими є постулати Володимира Мономаха: «Не ревнуй лукавнующимъ, ни завиди творящимъ безаконье, зане лукавнующии потребятся, терпящии же господа, - ти обладають землею. И еще мало, - и не будеть грЂшника; взыщеть мЂста своего, и не обрящеть. Кротции же наслЂдять землю, насладяться на множьствЂ мира» [2].

В умовах глобалізації та мультикультурного простору процес світоглядної ідентифікації суттєво ускладнюється й, очевидно, перманентно знаходиться в актуальному проблемному полі для гуманитарних наук. Небезпідставно ствердажує російський філософ Даніл Разєєв: «...в современных дискуссиях глобализация и культура являются понятийными коррелятами, причем всегда по отношению к третьему: политической теории. О культуре говорится в аспекте мультикультуральности, подрывающей в наши дни изнутри привычную форму национального государства, классически объединенного на основе единой территории, единого языка и единого происхождения населения; о глобализации же говорится в аспекте экономическом и информационном... Оказывается, что и культура, и глобализация несут с собой одну и ту же опасность для государства - потерю гражданина» [3]. Зрозуміло, що стан теоретикосвітоглядної невизначеності тут категорично не сприяє потрібній гармонізації моральнопсихологічної та соціально-політичної царин людського буття.

Сукупність морально-етичних, релігійно-філософських, політико-правових та інших пристрастей (антипатій і симпатій) людини оформлюється в етнічний колорит, що найяскравіше виявляється в народній творчості. Здобутки колективного розуму і душі є вельми аморфними за формою й еклектичними за змістом, що чітко визначає умонастрій переважної більшості людей. Таким чином, пошук консенсусу у вирішенні низки нагальних питань комунікації надає громадській думці ознак перманентного симбіозу різновекторних світоглядних позицій 3 подальшим встановленням хиткої рівноваги між ними у вигляді ментальної схильності.

Консолідуюча сутність громадської думки виявляється як отриманий у спадок від предків стан: з одного боку, від «віковічних» знань мудреців, вчителів, наставників, авторитетів, з іншого - від власних переживань, ретельно збережуваного або настійливо викорінюваного («позитивного» або «негативного») комунікативного досвіду. В культурно-антропологічному просторі, зазвичай, «уживаються» різноманітні естетичні смаки, різнорідні психотипічні реакції, строкаті релігійні вірування і багата палітра політичних переконань. У соціумі кожна адекватна людина прагне до комфортної екзистенції, тож і приречена на екстравертованість, що з молоком матері всмоктується як зацікавленість в Іншому (Собі Подібному або Категорично Чужому), оскільки саме від Нього, неодмінного, залежить і Власний добробут.

Посилюючи аргументацію щодо вищевикладеного, звернемося до міркувань Льва Гумильова, автора концепції «довгої волі»: «Положительным импульсом сознания будет только безудержный эгоизм, требующий для осуществления себя как цели рассудка и воли. ...Но ведь внутреннее давление - императив либо инстинкта, либо морали, либо пассионарности - также детерминирует поведение. Для «свободных» или «эгоистичных» импульсов остается небольшая, но строго очерченная область, та, где человек несет за свои поступки моральную и юридическую ответственность» [4]. Вірогідно, що бажання пасіонарного подолання відчуженості може, в міру розвиненості почуття власної гідності, створити трагічний прецедент саморуйнації та/чи ментальної колізії. Якщо в процесі самоідентифікації людина не сприймає себе як соціальний суб'єкт, який усвідомлює особисту міру відповідальності за суспільство, переконуємося в неперспективності такої комунікативної моделі, яка для остраху й настанови наступним поколінням, періодично «виринає» 3 анналів цивілізаційної історії. При повномасштабному розгортанні взаємного незадоволення діями один одного (втім, як i стосунками влади і народу), це може призвести, врешті-решт, до гуманітарної катастрофи. 
Потреба в мирному співіснуванні, що споконвіку формується в глибинах історичної пам'яті позачасова і $€$ загальнолюдським надбанням, отже, має незнищенну цінність, універсальне призначенння і необмежені в соціокультурному вимірі можливості. Саме тому справжня політична еліта віддає перевагу цивілізованим важелям впливу на суспільство, що і 3 господарсько-економічної, і з морально-етичної точок зору є менш енергозатратною, а відтак, більш привабливою моделлю суспільної комунікації. Адже як відомо з давніх-давен: поганий мир, кращий за хорошу війну, бо остання практично в рівній мірі становить загрозу для подальшого існування як влади, так і народу та $€$ не тільки безперспективним, а й небезпечним прецедентом для держави як «третейського суду» щодо двох вищезазначених суб'єктів соціальної взаємодії. Політичний Олімп завжди знаходиться в «подвійному оточенні»: як мінімум, незадоволеного поміркованого люду і, як максимум, розлюченого люмпенізованого натовпу, а також сусідних чи віддалених країн, серед яких завжди знайдеться той, кого спіткає спокуса взяти те, що погано лежить! I тут владі необхідно використовувати всі доступні цивілізовані фрорми впливу на буденну (масову) свідомість. Ми солідарні з позицією російського історика Олексія Черниша, який констатує факт широкомастабної взаємодії державних та релігійних інституцій по імплементації певних ідеологем у буденну (масову) свідомість: «Государство использует всю свою власть для поддержки решений церкви... Православие отождествлялось с мировоззрением, с системой готовых ответов на все вопросы человеческого существования» [5, с. 62]. Віру в рівність всіх перед Богом, Природою й Законом в соціальную практику, дійсно, повинні привносити духовно-моральні інституції (релігія, мистецтво, політика, право), від яких, насамперед, повинен вигравати народ, але й не в останню - влада.

Основою цивілізаційного ровитку очевидно й дотепер можна вважати сім'ю. Ї̈̈ соціалізуючі підмурівки відображаються в народному часописі, що охоплює найважливіші етапи ідентифікації кожного ії свідомого учасника, де за визначенням, Тут-Всі-Свої. При такій світоглядній настанові величезна увага приділяється не стільки релігійним або політичним подіям, скільки інтимноособистісним, що накладають смисловий відбиток на подальшу екзистенцію людини, бо їх вплив завжди пов'язується з емоційними переживаннями за будь-якого підтексту від контакту зі світом. Тому часто спостерігаємо дивовижне поєднання державних і народних свят, політеїстичних і монотеїстичних ритуалів, взаємопроникнення конфесійних і сімейних традицій тощо. Таким чином, у розмаїтому суспільному житті виникають цивілізовані стосунки лише тоді, коли вони ґрунтуються, насамперед, на загальнолюдських, а вже потім на політичних, релігійних, етнічних, сексуальних та інших групових чи індивідуальних цінностях.

«В каждый данный момент собственная структура индивидуального опыта обнаруживает в системах общества некоторый ряд возможностей (и невозможностей) выбора, а с другой стороны, социальные структуры обнаруживают в каждой своей точке выбор, сделанный (и не сделанный) рядом возможных индивидов», - небезпідставно вважав фрранцузький філософ Мішель Фуко [6, с. 398]. Жодним чином не принижуючи значення особистісної відповідальності за самореалізацію, все ж вважаємо за необхідне акцентувати на домінуючій ролі в цьому процесі саме оточення та громадської думки, оскільки реалізована особистість - це завжди результат колективної соціальної творчості.

Незнищенна потреба в значущості перманентної самоідентифікації виявляється критерієм життєздатності етносу. Тож, пошук державою оптимізуючих елементів в громадській думці і впровадження їх в політику як мистецтво можливого $є$ першочерговим завданням для відповідального, грамотного, розумного i, дійсно, компетентного здійснення урядом або правителем (що в даному випадку не змінює суті процесу): легітимація програми національного розвитку, апробація деяких положень і законів, ментально прийнятних або категорично неприйнятних ідей, механізмів реалізації декларативних обіцянок чи соціальних мрій.

У цьому контексті викликає зацікавленість та світоглядну підтримку аналіз українським філософом Сергієм Пролеєвим радянської ментальності під умовною назвою Гомо Совєтікус: «Таке «подвоєння» реальності у свідомості громадян призвело до того, що двоємислення стало інституційним елементом самої радянської дійсності... Цією мовчазною змовою - у вигляді перетинання паралельних світів - була просякнута вся пізня радянська дійсність. I ніхто 3 притомних людей (люди могли бути дурні, розумні, підлі, чесні, але зазвичай всі люди мали здоровий глузд) офріційну дійсність за дійсність не сприймали. Хоча всі, за винятком 
нечисленних дисидентів, виявляли лояльність... Несприйняття офріціозу не означає відсутності віри... Віра й критичне ставлення спокійно сполучалися у радянському менталітеті» [7, с. 197].

Готовність споживача ідеологем (від маргінала до інтелектуала) до постійної переоцінки цінностей як на політичному, так і буденному рівнях передбачає інтерактивність. При цьому суб'єкти соціальної дії повинні демонструвати необхідну кореляцію владних рішень 3 громадською думкою. Завжди актуальною є модель соціального управління, яка ґрунтується на одвічних прагненнях і бажаннях простої «середньостатистичної» людини матеріалізувати мислеобрази щасливого майбутнього. Очікуваною взаємною позитивною реакцією, з певним ступенем ймовірності, буде згенерований спільними зусиллями влади і народу моральнополітичний консенсус.

Акцентуючи увагу на абсолютній сакральності індивідуального (особистого) простору, останнім часом в середовищі мислячої гуманітарної громадськості все частіше фріксується «крен» до абсолютизації загальнолюдських цінностей. Адже особистість, яка відбулася - це завжди результативне поєднання як безпосередньо вимірюваного матеріально-конкретного, так і латентного віртуально-абстрактного впливу соціуму. Крім цього, жодне особисте бажання, мрія, ідея, мета не здійснюється поза ним. Якщо для цього громадянин і влада не навчаться домовлятися про умови, права та обов'язки кожного із них і створювати тим самим мирний комунікаційний майданчик з чітко прописаними межами свободи волі суб'єктів дії, то в такому соціумі розраховувати на успішну реалізацію ініційованих владою проектів і особистісну самореалізацію, очевидно, не доведеться.

В якості доказу вищевикладеної гіпотези пошлемося на дані соціологічного дослідження, проведеного в 2017 році в межах проекту «Залучення меншканців м. Чернігова до фрормування громадянського суспільства», в якому взяли участь 1717 жінок і 1243 чоловіки віком від 15 років, що відповідно становить 58\% і 42\% від загальної кількості респондентів, які були включені до вибірки та відповідає тодішній статистичній ситуації в місті Чернігові (Україна).

Метою і головним завданням моніторингу громадської думки, розуміння змісту якої надає реальні можливості її корекції як з боку державних інституцій, так і з боку громадських організацій, були визначені: 1) популяризація серед жителів міста ідеї створення впливової, політично грамотної спільноти, 2) фрормування у кожного свідомого і дієздатного містянина мотивації, знань і навичок, необхідних для відповідальної участі в громадській діяльності, 3) заохочення максимальної кількості учасників до співпраці з органами державної влади та місцевого самоврядування.

Очікувані результати дослідження громадської думки: розширення кола соціально активних громадян; підвищення рівня громадянської свідомості та обізнаності членів об'єднаної територіальної громади (ОТГ) щодо владних і персональних ініціатив і проектів; мотивація і стимулювання поведінки, заснованої на загальнолюдських цінностях; співпраця з громадськими організаціями та державними інституціями; збільшення сегмента громадян, які прагнуть до волонтерства; формування критичного мислення, політичної компетентності, навичок ведення публічних дискусій 3 актуальних питань життєдіяльності громади; сприяння прозорості прийняття управлінських рішень. За допомогою анкетування вивчалася громадська думка щодо дій влади, а також самооцінка можливостей і зусиль, які в сукупності $€$ індикатором перспективності наявної моделі соціального управління.

Досить переконливою (половина з тих, хто визначився і усвідомлює пріоритетність колективних інтересів по відношенню до індивідуальних) виглядає позиція містян, які дотримуються думки про те, що задля успішного вирішення актуальних проблем територіальної громади громадські організації та спілки повинні контролювати владу і лише близько п'ятої частини - активно рекламувати свою діяльність і проводити культурно-розважальну i просвітницьку роботу серед населення.

Привертає увагу досить зважена позиція чернігівців по відношенню до центральної та місцевої влади. Найефективнішою формою їх взаємодії для чверті опитаних вважається залучення громадських експертів в діяльність виконавчої влади. П'ята частина містян такими формами називають ініціювання та участь у загальних зборах мешканців, участь в громадських слуханнях та роботі рад.

Викликає стурбованість оцінка стану громадянської свідомості. На питання «Як Ви оцінюєте рівень громадянської свідомості й активності містян?» чернігівці відповіли наступним чином: 
приблизно $58 \%$ опитаних назвали його низьким або відсутнім, близько $28 \%$ вважають його достатнім або високим (останній показник послаблюється на тлі $15 \%$ тих респондентів, які не визначилися з відповіддю) (Рис. 1).

\section{РІВЕНЬ ГРОМАДЯНСЬКОї СВІДОМОСТІ}

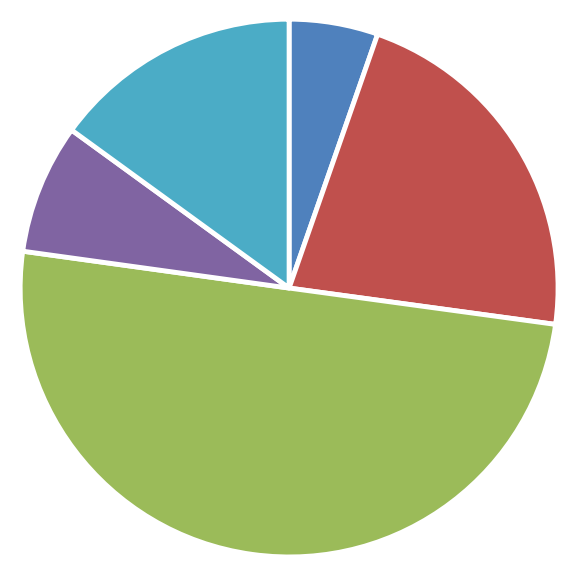

- Високий "Достатній " Низький "Відсутній "Важко сказати/Не знаю

Рис. 1 Електоральна оцінка рівня громадянської свідомості

Джерело: сформовано автором на основі [8]

Необхідно акцентувати увагу на тому, що лише близько десятої частини від числа опитаних $(9,3 \%)$ вважають святкування знакових подій в історії міста ефективною фоормою взаємодії 3 місцевою владою. Цей показник чітко корелює з потенційно протестним електоратом, який не налаштований на співпрацю і жодну із запропонованих анкетою позицій не сприймає як ефективну (9\%). Таке уявлення про форми взаємодії влади і народу у досить небагаточисельної кількості містян, на нашу думку, свідчить про поступове підвищення громадянської активності та їх колективної відповідальності, оскільки маргінальність і протестні настрої за останні кілька років мають тенденцію до зниження і на даний момент не перевищують 18\%. 3 урахуванням п'ятої частини тих, хто не визначився, ця цифрра мінімізується.

Опитування зафіксувало ще одну парадоксальну ситуацію: критичність і раціональність в оцінці життєдіяльності громади і влади (більше половини респондентів) накладається на в п'ять разів меншу кількість співгромадян, які політично й психологічно «дозріли» до активної політичної діяльності: таких, хто формально чи реально є членом громадських організацій або готується приєднатися до них, ледь перевищує $10 \%$.

Питання про професіоналізм політичного лідера сприяв приверненню уваги респондентів до соціальної відповідальності і перспективного мислення очільника громади чи співтовариства. На питання «Якою мірою на консолідацію суспільства впливатиме прихід до влади харизматичного і незалежного лідера?» електоральні симпатії у відсотковому співвідношенні розділилися наступним чином: 49,43 - сприятиме, 8,72 - категорично не сприятиме, 15,51 - не впливатиме ніяк, 25,51 - важко відповісти, не знаю.

В контексті взаємопроникнення моралі і політики акцентуємо увагу на професійних $\mathrm{i}$ людських якостях громадського або державного діяча. Тут переважна більшість чернігівців наполягають на необхідності максимальної прозорості, відвертості, чесності у висловлюваннях і діях публічної персони у взаєминах з громадою (58\%). Хоча авторитарний стиль керівництва в розумінні містян не є привабливим, все ж незначна частина $(4,5 \%)$ респондентів його схвалює. Ліберальному стилю керівництва віддають перевагу $16 \%$ опитаних. Серед тих, хто не визначився з відповіддю - 21,5\%, що може тлумачитись як досить тривожний показник соціальної байдужості чи принципової аполітичності (Рис. 2). 


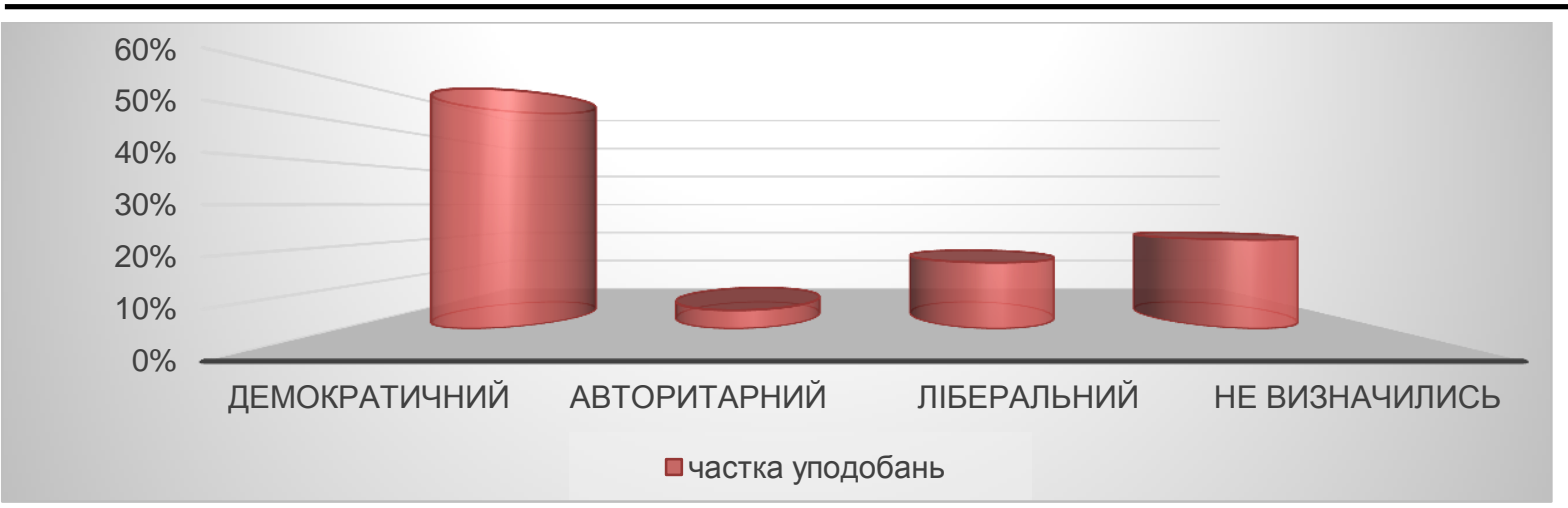

Рис. 2 Електоральні вподобання стилю управління

Джерело: сформовано автором на основі [8]

Оптимістично налаштованими виявились 57,87\%, містян, які віддають перевагу максимальній відвертості і чесності публічної персони перед громадою. В уподобаннях інших представників електорального поля професіоналізм, компетентність і мудрість керівника виглядає наступним чином: використання тактики поступового фрормування громадської думки, зважений реформістський підхід до соціального управління - 16,25\%, дозування інформації, замовчування негативних подій і проблем - 5,57\%, створення образу колективного ворога - 4,36\%, цензура, контроль за умонастроєм громади - 4,87\%, проповідництво, вміння мотивувати і надихати - 6,72\%, обмеження або уникнення громадським лідером публічних контактів з представниками засобів масової інформації (ЗМІ), делегування цього права політичним соратникам - 4,36\% (Рис. 3).

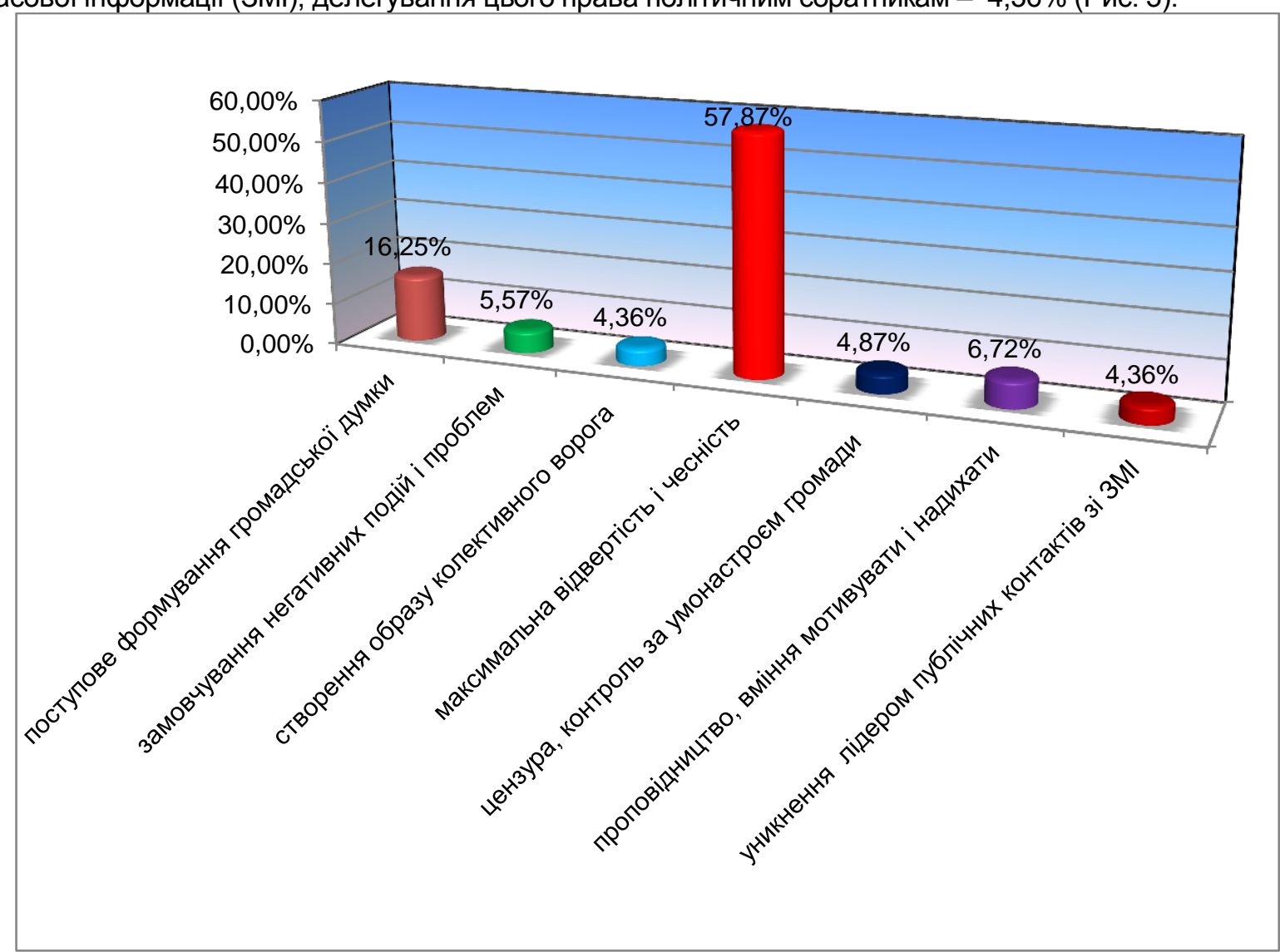

Рис. 3 Електоральне розуміння компетентності керівника

Джерело: сформовано автором на основі [8] 
Такий ментально-світоглядний зріз суспільної свідомості може свідчити про зростання кількості поціновувачів цивілізованих форм комунікації влади і народу, виникнення досить активної «критичної народної маси», яка визначає точку неповернення до тоталітарного суспільства і, як мінімум, усвідомлює пріоритет загальнолюдських цінностей по відношенню до групових та індивідуальних, як максимум, реально прагне послідовно втілювати принципи демократії і гуманізму у власній локації.

У людському бутті цей історично сформований вимір духовної культури є незаперечним доказом фундаментальної потреби кожного відповідального суб'єкта (будь то влада, народ, партія чи конкретна людина) вибудовувати відносини з іншим толерантно: ігнорувати світоглядні розбіжності там, де вони не зачіпають абсолютні цінності, щоб через подолання зрозумілих несуттєвих суперечностей слідувати принципам особистої толерантності та мультикультурної взаємодоповнюваності. Тут доречно послатися на більш детальний аналіз толерантності як випробування, переживання, мотиву, стану, категорії, реалії, кодексу честі тощо на різних етапах становлення людства і людяності, здійснений автором у науковій статті «Парадокси толерантності в контексті життєвої мудрості» [9, с. 62].

Висновки. Знання, що виходить із глибин буденної свідомості (поза конфесійними, етнічними, професійними, освітніми, гендерними, віковими та подібними вимірами) формує менталітет, особливості якого можна зрозуміти лише цілісно вивчаючи громадську думку як соціокультурний феномен, що виступає сполучною ланкою між індивідом і суспільством, очевидним загальноцивілізаційним надбанням, а відтак, основним комунікатором і регулятивом людського буття. Вона, будучи колективним розумом, мотивом і результатом спільної дії, a priori присутня у всіх видах соціальної активності людини і, тим самим, через ії моніторинг надає широкі можливості для гуманітаріїв, духовних лідерів, політиків в їх спробі ефективно впливати на суспільну свідомість.

Саме так може втілюватись в історію людства гуманізм з його пріоритетністю глобальних інтересів над локальними, усвідомленням необхідності законодавчої підтримки ідеї домінування загальнолюдських цінностей над будь-якими іншими, що є умовою стабільності та гармонізації суспільних стосунків. Найвливовішими регулятивами цього багаторівневого процесу, на нашу думку, $€$ мораль і політика, позаяк їх сутнісне призначення - структурування та ідеологіче оснащення духовного життя людської спільноти.

Громадська думка виступає єдиним надійним посередником або продуктивним компромісом між мораллю і політикою, що гарантує збалансоване співіснування влади і народу в перспективному соціумі. Гнучка демократична модель управління державою, своєю чергою, може з колосальним коефіцієнтом корисної дії використовувати колективний розум і волю у вирішенні нагальних проблем сучасності, глобальних і локальних соціально-політичних проектів. Чим консолідованішу позицію демонструє народ, тим більш підконтрольною і цивілізованою (моральною) стає влада, чим гнучкіша влада та мудріші чиновники та громадські діячі, тим більш політично грамотним стає народ і, як наслідок, формуються колективна відповідальність і громадянська свідомість.

Заохочення владою будь-якого прояву в буденній свідомості особистості та масовій свідомості спільноти відповідального, зацікавленого, співчутливого, оптимізуючого світовідношення як в морально-психологічному, так і в соціально-політичному вимірах $\epsilon$ підмурівком життєздатності людського співтовариства; небайдужість людини до проблем громади та ретельний моніторинг за діями влади $є$ необхідною умовою добробуту, стабільності, збалансованості інтересів різних суб'єктів соціальної дії, розвою духовної культури. Здатність поєднати політику і мораль у конкретній людській спільноті може стати гарантією успішного, взаємоприйнятного співіснування влади і народу та прогнозованого довголіття всіх учасників комунікації.

\section{Литература}

1. Маркс, К., Энгельс, Ф. Немецкая идеология // Собрание сочинений. 2-е изд. - М.: Политиздат, 1955. Т. 3. -689 с.

2. Володимиръ Мьномахы. Пооученью [Электронный ресурс] / Володимиръ Мьномахъ // Повчання Володимира Мономаха дітям [за Лаврентіївським списком] / Літопис Руський. - Режим доступа: http://litopys.org.ua/pvlyar/yar09.htm. 
3. Разеев, Д. Н. Плюральность мышления [Электронный ресурс] / Д. Н. Разеев // Studio culter. - 2003. - № 5 . - С. 57-83. - Режим доступа: https://portalus.ru/modules/philosophy/rus_readme.php?subaction=showfull\&id= $1108500504 \&$ archive $=0211 \&$ start from $=\& u c a t=\&$.

4. Гумилёв, Л. Н. Этногенез и биосфера Земли // Анналы. (1998). [Электронный ресурс]. - Режим доступа: http://gumilevica.kulichki.net/EAB/eab02.htm.

5. Черныш, А. М. Войти в душу народную: Отечественная мысль XIX-XX веков о характере руського народа. Научное издание / А.М.Черныш. - М. : Аспект Пресс, 2011. - 172 с.

6. Пролеєв, С. Філософія як школа життя за часів тоталітаризму. Частина І. Мислення в просторі радянських міфрів (Розмова зі Ксенією Зборовською, Русланом Мироненком,Оленою Костенко і Миколою Шульгою) [Электронный ресурс] / С. Пролеєв // Sententiae. - 2018 - 37 (2), 186-205. - Режим доступа: https://sententiae. vntu.edu.ua/index.php/sententiae/article/view/420/385

7. Фуко, Мишель. Слова и вещи. Археология гуманитарных наук [Электронный ресурс] / Фуко Мишель; пер. с фр. В. П. Визгина, Н. С. Автономовой; вступительная статья Н. С. Автономовой. - СПб., А-cad, 1994. - 408 с. - Режим доступа: https://platona.net//oad/knigi_po_filosofii/kulturologija/fuko_m_slova_i_veshhi_arkheologija gumanitarnykh nauk 1994/16-1-0-1615

8. Звіт Чернігівській міській раді про результати соціологічного дослідження «Моніторинг думки чернігівців щодо життєдіяльності місцевої громади та соціально-політичної ситуації в Україні» (в межах проекту бюджету м. Чернігова 2017 року «Залучення мешканців м. Чернігова до формування громадянського суспільства»). - Чернігів : Чернігівський національний технологічний університет, кафедра фрілософіії і суспільних наук, 2017.

9. Киселиця, С. В. Парадокси толерантності у контексті життєвої мудрості [Електронний ресурс] / С. В. Киселиця // Вісник Черкаського університету. Серія «Філософрія». - 2015. - Вип. 31 (364). - С. 59-66. - Режим доступа: http://philosophy-ejournal.cdu.edu.ua/article/view/373/387/.

\section{References}

1. Marx, K., Engels, F. (1955). Nemetskaya ideologiya [German ideology]. Sobranie sochineniy - Collected Works. (Vols. 3). (2nd ed.). Moscow: Politizdat [in Russian].

2. Vladimir Monomakh (1990). Povchannia Volodymyra Monomakha (Za Lavrentiivskym litopysom 1377 r.) [The teachings of Vladimir Monomakh (According to the Laurentian Chronicle 1377)]. Retrieved from: http://litopys.org.ua/pvlyar/yar09.htm [in Russian].

3. Razeev, D. N. (2005). Plyuralnost myshleniya (Plurality of thinking). Moscow: Nauchnaya tsifrovaya biblioteka. Retrieved from https://portalus.ru/modules/philosophy/rus_readme.php?subaction=showfull\&id=1108500504\&archive= 0211\&start_from $=\& u c a t=\&$ [in Russian].

4. Gumilev, L.N. (1989). Passionarnost [Passionner]. Retrieved from http://gumilevica.kulichki.net/EAB/eab02.htm [in Russian].

5. Chernysh, A. M. (2011). Voyti $v$ dushu narodnuyu: Otechestvennaya mysI XIX-XX vekov o kharaktere russkogo naroda Entering the soul of the people [Domestic thought of the 19th-20th centuries about the character of the Russian people)]. Moscow: Aspekt Press [in Russian].

6. Proleiev, S. (2018). Filosofiia yak shkola zhyttia za chasiv totalitaryzmu. Chastyna I. Myslennia v prostori radianskykh mifiv (Rozmova zi Kseniieiu Zborovskoiu, Ruslanom Myronenkom,Olenoiu Kostenko i Mykoloiu Shulhoiu) [Philosophy as a school of life in the days of totalitarianism. Part I. Thinking in the space of Soviet myths)]. Sententiae, 37(2), 186-205. Retrieved from: https://sententiae.vntu.edu.ua/index.php/sententiae/article/view/420/385 [in Ukrainian].

7. Foucault, M. (1994). Slova $i$ veshchi. Arkheologiya gumanitarnykh nauk. (Words and things. Archeology of the Humanities). (V. P. Vizgin, N. S. Avtonomova, Trans). Saint Petersburg: A-cad. Retrieved from https://platona.net/load/knigi po filosofii//kulturologija/fuko_m slova_i_veshhi_arkheologija gumanitarnykh nauk_1994/16-1-01615 [in Russian].

8. Zvit Chernihivskii miskii radi pro rezultaty sotsiolohichnoho doslidzhennia «Monitorynh dumky chernihivtsiv shchodo zhyttiediialnosti mistsevoi hromady ta sotsialno-politychnoi sytuatsii v Ukraini» (v mezhakh proektu biudzhetu m. Chernihova 2017 roku "Zaluchennia meshkantsiv m. Chernihova do formuvannia hromadianskoho suspilstva») [Report to the Chernihiv City Council on the results of the sociological survey "Monitoring the opinion of Chernihiv residents on the life of the local community and socio-political situation in Ukraine" (within the draft budget of Chernihiv in 2017 "Involvement of Chernihiv residents in the formation of civil society")]. (2017). Chernihiv : Chernihivskyi natsionalnyi tekhnolohichnyi universytet, kafedra filosofii $\mathrm{i}$ suspilnykh nauk [in Ukrainian].

9. Kyselytsia, S. V. (2015). Paradoksy tolerantnosti u konteksti zhyttievoi mudrosti [Paradoxes of tolerance in the context of life wisdom]. Visnyk Cherkaskogo universytetu. Seriya "Filosofiya» - Visnyk of Cherkasy University. Philosophy series, 31(364), 59-66. Retrieved from: http://philosophy-ejournal.cdu.edu.ua/article/view/373/387/ [in Ukrainian].

Бібліографічний опис для цитування :

Надійшла 21.11.2019

Киселиця, С. В. Громадська думка як морально-політичний регулятив людського буття / С. В. Киселиця // Проблеми соціальної роботи: фрілософрія, психологія, соціологія. - 2019. - № 2 (14). - С. 42-51. 